\title{
European Union consumer policy on product safety in years 2002-2014
}

\begin{abstract}
The article aims to analyse consumer policy in the field of product safety in the European Union after 2002. In particular the considerations focus on the legislative and standardization activities of the Union in the area of product safety. The article synthesised selected acts of European Union law in the field of product safety. In particular, the basic objectives of consumer policy after 2002 were presented in the context of product safety. It also pointed to the essence of the standardization process of the product safety standards in the European Union. It was pointed out that the RAPEX and RASFF systems contribute to consumer safety. The final part of the article contains considerations on the legitimacy and real impact of the standardization process in the field of product safety.
\end{abstract}

Key words: product safety, consumer, consumer policy, consumer rights, European Union

\section{Introduction}

E nsuring a high level of protection of consumers as regards health, safety and economic interests as well as promoting their right to information, education and organization are, according to Article 169 of the Treaty on the Functioning of the European Union (TFEU), tasks of the European Union (Consolidated versions of the Treaty on the European Union, 2012). The EU exercises this competence by creating consumer legislation, in particular in the form of secondary legal acts having binding force (regulations, directives) and non-binding legal acts, creating the desired standards of consumer protection, often in the form of consumer policy strategies and programs (resolutions, communications, recommendations, opinions). Member states must respect EU law and adapt their consumer legislation to it. They may create national legal regulations providing a higher level of consumer protection; however, taking into account the Treaty freedoms and the principle of proportionality. (Micklitz, Weatherill, 1993, p. 300).

The subject of this article is an analysis of consumer policy in the field of product safety in the years 2002-2014. The considerations focus in particular on the legislative activities of the European Union in the area of product safety, with special emphasis on consumer policy programs and strategies during the indicated period.

The chronological scope of the research covers the years 2002-2014. The initial turning point is the signing of the Nice Treaty and the publication of the EU consumer policy program of the European Union for the years 2002-2006. With the considerations ending in 2014 with an indication of the basic assumptions in the field of product safety, the policy document for 2014-2020 articulated EU actions to strengthen the level of protection of consumer rights on the common market. 
The following research hypotheses were critically reviewed in the article: firstly, minimum standards regarding product safety are created in EU consumer policy programs and strategies. They are adapted to real current economic, health, information and educational threats as well as in the field of redress. Secondly, the hypothesis was adopted that the implementation of consumer policy assumptions in the field of product safety takes place through the creation of appropriate legal standards and through the broadly understood standardization process.

During the implementation of the research problem discussed, numerous social science research methods and techniques were applied. The primary research method used in the article is the dogmatic analysis method. It was used to analyse EU and national legal acts and EU consumer policy programs. The article also uses the comparative method to compare selected aspects of product safety in EU consumer policy programs implemented in 2002-2014. In the study of consumer policy in the field of product safety in the EU, the analysis of selected legal acts was of fundamental importance. The texts of EU strategies and policy programs in the years of 2002-2014 were used, in which postulates and actions concerning product safety were highlighted.

Consumer safety in the European Union after 2002 is shaped on two basic levels. Firstly, in connection with the creation of appropriate legal regulations (primary and secondary law), aimed at protecting consumers against products harmful to their life and health. Secondly, regarding the development of standardization and control institutions as well as the need for education and consumer information about the potential risks of using a dangerous product. Consumer policy programs and strategies also play an important role.

On February 26th, 2001, the Nice Treaty, amending the Treaty on the European Union and the Treaties establishing the European Communities as well as certain related legal acts, introduced regulations having an indirect impact on the safety of products (Treaty of Nice amending the Treaty on European Union...). It concerned the competences of the Economic and Social Committee. From then, it was of an advisory nature - it was concerned with issuing opinions in the case of creating legal regulations in the field of product safety among others (Hambura, Muszyński, 2001, p. 19). After the Nice Treaty, EU consumer policy goals regarding product safety were formulated in consumer policy programs and strategies.

\section{General product safety requirements in the European Union and standardization}

The concept of European standardization in the context of consumer product safety can be understood as the harmonization of consumer norms and legal standards in member states in the broadly understood processes of manufacturing, purchasing and use of products. The main purpose of European standardization is to define voluntary technical or quality specifications to which current or future products, production processes or services may conform. Standardization may address various issues, such as the standardization of different classes or sizes of a given product or technical specifications in product or service markets where compatibility and interoperability with other products and systems are necessary (Regulation (EU) No 1025/2012...). 
The harmonization of technical standards for consumer products has a fundamental impact on ensuring the health and economic safety of European consumers. As regards health and safety, it is about creating such legal standards and commercial practices that eliminate the admission to sale of consumer products that threaten the life and health of buyers. Concerning economic security, we can talk about an efficient unified system of cross-border redress and access to a diverse range of products at competitive prices that meet relevant security standards. In the 1980s, the so-called new approach to technical harmonization was adopted. It was based on the principle that a product can enter the market only if it meets the essential requirements of the „new approach directives.” These directives are mandatory legal provisions to be implemented by all EU members. They apply to specific groups of products (e.g. toys, machines, elevators) or types of risk or phenomena (noise emissions, electromagnetic compatibility). A product may therefore be covered by several of them, and in this case it must meet the requirements of all relevant directives. The manufacturer, analysing the features of the product and the risks it causes, must assess whether the product falls within the scope of one directive or several (Polski przedsiębiorca w Unii Europejskiej..., 2005, p. 7).

Legal harmonization was limited to essential safety requirements or other social requirements that products entering the market, and therefore subjected to free movement in the European Union, had to comply with. It also involved the development of technical specifications for production by competent institutions in the field of industrial standardization, which took into account the state of technology. Administrative authorities were required to grant products manufactured in accordance with harmonised standards a presumption of conformity with the essential requirements set in the directive.

In the event that a company did not manufacture in accordance with these standards, they were obliged to comply with the essential requirements (Council Resolution of $71985 \ldots)$. The primary goal of these directives was to ensure the protection of buyers' health and to guarantee consumers that the products available in the EU single market are safe and comply with applicable global standards (Miedzińska, 2016, pp. 80-82).

Another element of European standardization ensuring increased consumer safety was the implementation of the principle of mutual recognition (Communication from the Commission..., 1999). According to the above principle, a product that meets legal regulations and standards in the country of production, and which legally entered the market there, can be sold throughout the European Union.

The creation of uniform global conditions for assessing the compliance of products with the essential requirements was also a factor affecting the safety of European consumers. The global approach to conformity assessment identified the main elements of testing and certification, as well as rules for designating bodies involved in the assessment of products, and also unified the rules for placing and applying the CE marking. The new rules and global approach only covered some sectors of the economy. The marking of products subject to the new approach directives with the „CE” mark was in practice the manufacturer's declaration that the product was subjected to conformity assessment and meets the essential requirements. If the product was subject to such marking, it could not be marketed without it. (Polski przedsiębiorca w Unii Europejskiej..., 2005, pp. 20-21).

In conclusion, only products that comply with normalization standards may be marketed in the European Union. The directive on general product safety indicates that prod- 
ucts which enter the EU market must meet general safety requirements as well as conformity assessment criteria and European standards (Directive 2001/95/EC...). In Article 3 of the directive, as a rule, producers are required to market only safe products. A product is considered safe if (in the absence of specific transnational regulations governing the safety of a given product) it complies with the requirements of specific national legislation of the member state on whose territory the product is sold. A product is considered safe when it complies with national standards transposing relevant European standards, standards developed in the member state where the product is sold or Commission recommendations setting guidelines for the safety assessment of the product. Codes of good practice in the sector in question in relation to product safety and the level of workmanship and technology used, as well as possible consumer expectations with regard to safety, are also of significant importance.

In the European Union, product safety is supervised by RAPEX (Rapid Exchange Information System for Non-food Consumer Products) and RASFF (Rapid Alert System for Food and Feed) systems. RAPEX pursuant to art. 12 of Directive 2001/95/EC is a Community rapid information system for the swift exchange of information between member states and the Commission regarding measures and actions taken in relation to products posing a serious risk to the health and safety of consumers. The RAPEX system helps prevent products that pose a serious threat to the health and safety of consumers from entering the European market. It facilitates monitoring the effectiveness and consistency of market surveillance and activities related to enacting the law in the member states. It also provides a basis for identifying the need for action at EU level and serves to consistently enforce EU requirements on product safety and the smooth functioning of the internal market (Decisions of the Commission of 16 December 2009...).

RASFF, an early warning system for dangerous food products and animal feed, is a tool for the control bodies of the member states, the Commission and the European Food Safety Authority to notify food and feed hazards to humans. In art. 50 of Commission Regulation (EU) No 16/2011 of 10 January 2011, the scope and requirements for the operation of the RASFF system were established. Member states are primarily responsible for enforcing the EU law. They conduct official controls (Regulation (EC) No $882 / 2004 \ldots$..). As a rule, the RASFF system supports the activities of the member states, allowing rapid exchange of information on food and feed hazards as well as on measures that are in place or are planned to be taken to counter such threats (Commission Regulation (EU) No 16/2011...).

\section{Product safety in consumer policy programs in the European Union}

The European Union's consumer policy has been developed in programs and strategies covering a period of several years. They take the form of European Commission communications, and although they do not have legally binding force, they create specific standards in the field of consumer protection. They contain overarching goals and ways of achieving them aimed at improving consumer safety.

Since 2002, the objectives of consumer policy in the EU have been set out in the Statement from the Commission to the European Parliament, the Council, The European 
Economic and Social Committee of the Regions on the consumer policy strategy for 2002-2006 (Communication from the Commission of 7 May 2002...).

The consumer policy strategy for 2002-2006 pointed to the need to improve product safety as an essential element of consumer protection. The free movement of consumer products required the adoption of joint or at least convergent regulations ensuring at the same time sufficient protection for the interests of consumers. It was also planned to enable consumers to make autonomous informed choices about goods and services throughout the European Union. This consisted, among others, in providing consumers with sufficient appropriate information prior to a transaction (point 2). The strategy provided for three ,mid-term objectives" to be achieved through a series of activities over a five-year period. They contained short-term actions that could be quickly adapted to changing circumstances (point 2.4) (Wysokińska, Witkowska, 2004, pp. 2010-2014).

The first goal related to the regulation of simple rules, among others in the field of consumer product safety. To this end, on July 20, 2004, the European Commission's Directorate General for Health \& Consumer Protection adopted ten basic rules for consumer protection in the EU. They did not constitute formal guidelines of the Commission; however, they reflected a certain minimum that member states should meet in the area of consumer protection (Haidar, 2005). In particular, they involved the harmonization of specific directives and standards to guarantee the safety of goods. The implementation of the above-mentioned goal required the undertaking of numerous actions aimed at ensuring the safety of consumer products and free movement of consumer goods and services (point 3.1.1). The priority was the implementation of the amendment to Directive 2001/95/EC of the European Parliament and of the Council of December 3, 2001 on general product safety, in particular the development of initiatives directed at consumers in the field of product safety.

Striving to ensure transparency and adequate representation of consumer interests in the international standardization process was an important activity of the Commission in the years 2002-2006 in the field of guaranteeing the safety of consumer products. The Commission announced the promotion and protection of consumer interests in the World Trade Organization (WTO), as well as in the context of bilateral contractual relations (point 3.1.6) (Hoekman, Kostecki, 2002, pp. 17-19).

Another goal of the strategy was effective cooperation in the enforcement of consumer rights rules (section 3.2). Actions taken at this level included four short-term goals. Among others, these included cooperation between member states in the field of commercial practices and product safety, and ensuring adequate information in the field of the safety of goods and services.

The last goal of the Commission in the years 2002-2006 was to ensure that consumer organizations would have the right influence European Union consumer policy. These organizations were to influence initiatives aimed at improving product safety standards (section 3.3.1.2) among others. In summary, the EU Consumer Policy Strategy for 2002-2006 concluded that consumers purchasing goods and services within the EU should be subject to the same protection.

The next European Union consumer policy strategy, for 2007-2013 (Communication from the Commission to the Council, The European Parliament and the European Economic and Social Committee EU Consumer Policy strategy 2007-2013...), indicates 
in point 1 that this policy should be more focused on consumer safety, as consumers are the cornerstone of the EU economy and their choices stimulate innovation and productivity. The strategy indicates that the consumer dimension of the retail internal market, related to the purchase of products and services, required further strengthening. It aims at eliminating fragmentation in domestic markets and creating one common retail market. Consumer policy should influence the regulations regarding the safety of consumer products and promote access to goods and services at affordable prices. It should also contribute to the realization and promotion of fundamental European values around the world, which are justice, openness, solidarity, sustainable development and transparency. The overarching contemporary policy goal is to ensure adequate protection across the EU for consumers against dangerous products and dishonest traders (Nowak, 2007, pp. 3-5). The Commission is to strive to ensure a high level of consumer protection through appropriate legal regulations, raising consumers' knowledge of product safety, increasing the scope and importance of improving public consultation and better representing consumer interests.

Point 2 of the Statement indicates the main challenge facing the Community. It concerned, among others, enabling consumers to make informed decisions regarding the purchase of consumer products within the comprehensive market created. A positive aspect of the diversity of retail products in the single market and the wider selection of goods and services was also emphasised. For most consumers, this situation is favourable and strengthens their position in the market. However, it may pose a potential threat to consumers who are particularly vulnerable to abuse, namely children and the elderly. Further liberalization of the electricity, gas, postal and telecommunications sectors was planned. This process should be accompanied by effective market scrutiny (point 2.1).

The accession of new countries to the European Union in 2004 and 2007 meant the development of open markets and their adoption of EU standards in the field of consumer product protection. Therefore, the basic task of EU consumer policy in 2007-2013 became to guarantee that goods and services would be safe and markets would be fair and transparent. This would allow the exclusion of unfair traders from the market, while making it easier for consumers to make purposeful and informed choices (section 2.2).

During the period described, the Commission would seek to achieve three priority objectives. The first concerned the empowerment of EU consumers by guaranteeing reliable information, real protection and stable rights. Another related to increasing consumer welfare in terms of prices, choice, quality, diversity, affordability as well as the safety of goods and services. The third objective was to provide effective protection for consumers against dangers that they cannot cope with themselves (point 3), including those related to the purchase of defective and dangerous products (Dąbrowska, Janoś-Kresło, 2007, pp. 135-140). In order to achieve its objectives, EU consumer policy focuses on five priority areas (point 4). One of them is activities in the field of consumer safety. Its priority is the functioning of a community-wide system of collecting data on injuries and accidents related to products and services, and improvement of knowledge in the field of threats related to the safety of goods and services. The existing joint research project 'EIS-Chem Risks' would also be continued (point 5.1). The project concerned a European information system on the dangers of chemical substances released by consumer products. 
The second priority action in the field of EU consumer policy for 2007-2013 is the improvement of legal regulations in the field of consumer protection. The regulations in force in the EU are to guarantee basic protection for consumers in all member states. As a result of research conducted, it was found that regulations regarding broadly understood products, services and sales channels are increasingly not adapted to the digital revolution in the economy. Therefore, the Commission launched consultations in these areas. An important problem was the principle of ,minimum harmonization” applied in most EU legislation on consumer protection. The tasks of the Commission also include the modernization and simplification of legal provisions regarding the safety of consumer products. The development of the RAPEX market supervision and early warning system would be continued. Effective redress mechanisms when shopping outside one's country are a guarantee of consumer confidence. Therefore, the Commission would strengthen the monitoring system and encourage the use of Alternative Dispute Resolution (ADR) - point 5.3 (Commission Recommendation 2001/310/EC...).

The fourth priority is related to better information and education of consumers, including in the area of product and service safety. It manifests itself in close cooperation with EU member states in the field of actions taken on national, regional and local levels regarding consumer information and education. The EU contact point with consumers in the form of the European Consumer Centres Network, which should continue to further develop, is of particular importance here. ECC-Net provides advice to consumers on their rights, as well as facilitates access to legal appeals for cross-border purchases (section 5.4).

The overall objective of the Consumer Policy Program for 2014-2020 (Regulation (EU) No 254/2014...) is to ensure a high level of consumer protection as well as to empower consumers and to position the consumer at the heart of the internal market as part of an overall strategy for smart, sustainable and inclusive growth. The general objective is achieved through four detailed objectives. One of them concerns strengthening and increasing product safety through effective market supervision throughout the EU. The activities and effectiveness of the EU early warning system on dangerous consumer products (RAPEX) will especially be used to measure the realization of this objective. The specific goals referred to in art. 3, are implemented through the eligible actions listed below. The indicated objective is to be implemented through three qualified actions. The first relates to scientific consultation and risk analysis in the area of consumer health and safety in relation to non-food products and services. It is associated with the performance of the tasks by independent scientific committees established on the basis of Commission decision 2008/721/EC (Commission Decision of 5 August 2008...). The next one consists in coordinating activities related to market surveillance and law enforcement in the field of product safety in relation to Directive 2001/95/EC of the European Parliament and of the Council as well as other activities aimed at increasing the safety of consumer services. The final one is aimed at maintaining and expanding cosmetics databases that threaten the health or even the life of consumers. The cosmetics made available on the market should be safe for the health of consumers under normal or foreseeable conditions of use. They should have appropriate markings, instructions for use and disposal as well as all other relevant information necessary for correct use (Article 3) (Regulation (EC) No 1223/2009...). 


\section{Conclusion}

Product safety is an important element of the European Union's consumer policy. In each of the EU consumer policy programs after 2002, product safety in the European Union was indicated as the primary goal. However, the programs differed in the measures to implement it. It seems indisputable that consumers in the European Union should be certain that the products they buy are safe for their health and life. An appropriate standardization and harmonization system is aimed at guaranteeing this principle. Unification of legal norms and standards in member states in the broadly understood process, design and production of consumer products is a process of fundamental importance for the safety of buyers. A well-protected consumer purchasing safe products can feel that they are a full-fledged market entity and be willing to purchase products outside the borders of their member state. The standardization of technical and legal standards also promotes the development of free competition and sets equal requirements for European manufacturers.

The participation of consumer representatives in consultation bodies and action groups, as well as in the EU institutions, also ensured the provision of consumer involvement in the standardization process affecting the safety of EU products. Consultations between European and national consumer organizations took place at the level of the European Parliament and the Council, and after the Treaty of Nice also in the Social and Economic Committee (Article 257 of the Treaty). Non-governmental consumer organizations (NGO's) operating at Community level play an important role in creating product safety standards. The largest and most influential non-governmental consumer organizations operating at EU level and cooperating with EU decision-making institutions include the Bureau Européen des Unions de Consommateurs (BEUC), the Confederation of Family Organizations (COFACE) and the European Association for the co-ordination of Consumer Representation in Standardization (ANEC). Despite the fact that their activity is of mainly educational and informational character, as well as providing scientific advice, through numerous campaigns and initiatives, combined with already developed lobbying activities, they stress the need to introduce appropriate legal solutions and the need for consumer products to meet specific technical standards (Pointer, 2002, pp. 45-47).

\section{Bibliography}

Commission Recommendation of 4 April 2001 on the principles for out-of-court bodies involved in the consensual resolution of consumer disputes, OJ L 109/56, 19.04.2001.

Commission Regulation (EU) No 16/2011 of 10 January 2011 laying down implementing measures for the Rapid alert system for food and feed, OJ UE L6/7, 11.01.2011.

Communication from the Commission to the Council and the European Parliament - Mutual recognition in the context of the follow-up to the action plan for the single market, 16.06.1999, COM/99/0299.

Communication from the Commission to the Council, The European Parliament and the European Economic and Social Committee EU Consumer Policy strategy 2007-2013 Empowering consumers, enhancing their welfare, effectively protecting them, $\operatorname{COM(2007)~99,~13.03.2007.~}$ 
Communication from the Commission of 7 May 2002 to the European Parliament, the Council, the Economic and Social Committee and the Committee of the Regions - "Consumer Policy Strategy 2000-2006”, COM (2002) 208, 7.05.2002.

Council Resolution of 7 May 1985 on a new approach to technical harmonization and standards, OJ C 136, 4.06.1985.

Consolidated versions of the Treaty on European Union and the Treaty on Functioning of the European Union 2012/326/1, OJ EU 26.10.2012.

Dąbrowska A., Janoś-Kresło M. (2007), Konsumpcja w krajach Europy Środkowo-Wschodniej, Polskie Wydawnictwo Ekonomiczne, Warszawa.

Decisions Commission of 16 December 2009 laying down guidelines for the management of the Community Rapid Information System 'RAPEX' established under Article 12 and of the notification procedure established under Article 11 of Directive 2001/95/EC (the General Product Safety Directive), O.J. L 22/1, 26.1.2010.

Directive 2001/95/EC of the European Parliament and of the Council of 3 December 2001 on general product safety, O.J. L 11/4, 15.1.2002.

Haidar K. (2005), Konsument dobrem wspólnotowym, „Biuletyn Inspekcji Handlowej”, no. 2.

Hambura S., Muszyński M. (2001), Traktat z Nicei z komentarzem, Wydawnictwo Studio Bielsko-Biała, Bielsko-Biała.

Hoekman B., Kostecki M. (2002), Ekonomia światowego systemu handlu. WTO: zasady i mechanizmy negocjacji, Wydawnictwo Uniwersytetu Ekonomicznego we Wrocławiu, Wrocław.

Miedzińska I. (2016), Nowe podejście do harmonizacji technicznej w Unii Europejskiej a swoboda przepływu towarów, „Przegląd Europejski”, no. 2.

Micklitz H. W., Weatherill S. (1993), Consumer policy in the European Community: Before and after Maastricht, "Journal of Consumer Policy", no. 3-4.

Nowak S. (2007), Nowe wyzwania i priorytety. Wokót strategii polityki konsumenckiej Unii Europejskiej na lata 2007-2013, „Biuletyn Inspekcji Handlowej”, no. 2.

Pointer S. (2002), Promoting Consumer Confidence in e-Commerce: The 'Brussels Regulation'-Real or Illusory Consumer Benefit? The Business Case, in: European Union Lobbying, ed. R. Pedler, New York.

Polski przedsiębiorca w Unii Europejskiej. Wyroby podlegajace ocenie zgodności i oznakowaniu CE (2005), Warszawa.

Regulation (EU) No 1025/2012 of the European Parliament and of the Council of 25 October 2012 on European standardisation, amending Council Directives 89/686/EEC and 93/15/EEC and Directives 94/9/EC, 94/25/EC, 95/16/EC, 97/23/EC, 98/34/EC, 2004/22/EC, 2007/23/EC, 2009/23/EC and 2009/105/EC of the European Parliament and of the Council and repealing Council Decision 87/95/EEC and Decision No 1673/2006/EC of the European Parliament and of the Council, L316/12, 14.10.2012.

Regulation (EU) No 254/2014 of the European Parliament and of the Council of 26 February 2014 on a multiannual consumer programme for the years 2014-2020 and repealing Decision No 1926/2006/EC, L 84/42, 20.3.2014.

Regulation (EC) No 1223/2009 of the European Parliament and of the Council of 30 November 2009 on cosmetic products, OJ L 342/59, 22.12.2009.

Regulation (EC) No 882/2004 of the European Parliament and of the Council of 29 April 2004 on official controls performed to ensure the verification of compliance with feed and food law, animal health and animal welfare rules, OJ L 165, 30.04.2004.

Treaty of Nice amending the Treaty on European Union, the Treaties establishing the European Communities and certain related acts, signed at Nice, 26 February 2001 - Contents, O.J. C 80, 10.03.2001. 
Wysokińska Z., Witkowska J. (2004), Integracja Europejska. Dostosowania w dziedzinie polityk, Polskie Wydawnictwo Ekonomiczne PWE, Warszawa.

\section{Polityka konsumencka Unii Europejskiej w zakresie bezpieczeństwo produktów w latach 2002-2014}

\section{Streszczenie}

Artykuł ma na celu analizę polityki konsumenckiej w zakresie bezpieczeństwa produktów w Unii Europejskiej po 2002 roku. Rozważania koncentrują się w szczególności na działaniach prawodawczych oraz normalizacyjnych Unii na płaszczyźnie bezpieczeństwa produktów. W artykule dokonano syntezy wybranych aktów prawa pierwotnego i wtórnego Unii Europejskiej w zakresie bezpieczeństwa produktów. W szczególności przedstawiono podstawowe cele polityki konsumenckiej po 2002 roku w kontekście bezpieczeństwa produktów. Wskazano również na role procesu normalizacyjnego na standardy bezpieczeństwao produktów w Unii Europejskiej. Wskazano na zasadność funkcjonowania systemów RAPEX (Rapid Exchange Information System for Non-food Consumer Products) i RASFF (Rapid Alert System for Food and Feed) przyczyniających się do bezpieczeństwa nabywców. Ostatnia część artykułu pełni rolę konkluzji, zawiera rozważania na temat zasadności oraz rzeczywistego wpływu normalizacji na ich bezpieczeństwo.

Słowa kluczowe: bezpieczeństwo produktów, konsument, polityka konsumencka, prawa konsumenta, Unia Europejska 